\title{
Long-Term Trends in News Content
}

\author{
Humprecht, Edda ; Udris, Linards
}

\begin{abstract}
The way news is produced and consumed has changed dramatically during the first two decades of the 21 st century due to digitalization and economic pressures. In a globalized world, current events are reported in almost real time in various countries and are diffused rapidly via social media. Thus much scholarly attention is devoted to determining whether these developments have changed news content. Comparative research in the area of journalism focuses on whether news content across countries converges over time and to what degree national differences persist across countries. When studying the research on long-term trends in news content, three main observations can be made. First, theoretical assumptions are often rooted in different models of democracies, but they are rarely explicitly discussed. Second, many studies focus on the organizational level using theoretical concepts related to increased market orientation of news outlets, such as personalization, emotionalization, or scandalization. Furthermore, commercialization is associated with the effects of digitalization and globalization, namely, decreased advertising revenues and increased competition. A commonly expressed fear is that these changes have consequences for democracy and informed citizenship. Third, in recent years, there has been a steady increase of studies employing international comparisons as well as a growing standardization for measurements. These developments lead to more multicountry studies based on large samples but come at the expense of more fine-grained analysis of the way news content changes over time. Finally, the vast majority of cross-national and single-country studies focus on Western democracies. Thus our knowledge about recent changes in news content is limited to a small set of countries. Overall, many studies provide evidence for constant changes of news content driven by social, political, and economic developments. However, different media systems exhibit a sustained resilience toward transnational pressures reflected in a persistence of national differences in news content over time.
\end{abstract}

DOI: https://doi.org/10.1093/acrefore/9780190228613.013.838

Posted at the Zurich Open Repository and Archive, University of Zurich

ZORA URL: https://doi.org/10.5167/uzh-157449

Book Section

Accepted Version

Originally published at:

Humprecht, Edda; Udris, Linards (2019). Long-Term Trends in News Content. In: Örnebrink, Henrik. Oxford Research Encyclopedia of Communication. Oxford, UK: Oxford University Press, 1-22.

DOI: https://doi.org/10.1093/acrefore/9780190228613.013.838 


\section{Long-Term Trends in News Content}

Edda Humprecht \& Linards Udris

Humprecht, Edda; Udris, Linards (2019): Long-Term Trends in News Content. In: Örnebrink, Henrik (Ed.): Oxford Research Encyclopedia of Communication (Journalism Studies). Oxford: Oxford University Press.

http://oxfordre.com/communication/view/10.1093/acrefore/9780190228613.001.0001/acrefore$\underline{9780190228613-\mathrm{e}-838}$

\section{Summary}

The way news is produced and consumed has changed dramatically during the first two decades of the $21^{\text {st }}$ century due to digitalization and economic pressures. In a globalized world, current events are reported in almost real time in various countries and are diffused rapidly via social media. Thus, much scholarly attention is devoted to determining whether these developments have changed news content. Comparative research in the area of journalism focuses on whether news content across countries converges over time and to what degree national differences persist across countries.

When studying the research on long-term trends in news content, three main observations can be made. First, theoretical assumptions are often rooted in different models of democracies, but they are rarely explicitly discussed. Second, many studies focus on the organizational level using theoretical concepts related to increased market-orientation of news outlets, such as personalization, emotionalization, or scandalization. Furthermore, commercialization is associated with the effects of digitalization and globalization, namely, decreased advertising revenues and increased competition. A commonly expressed fear is that these changes have consequences for democracy and informed citizenship. Third, in recent years, there has been a steady increase of studies employing international comparisons as well as a growing standardization for measurements. These developments lead to a growing number of multi-country studies based on large samples but come at the expense of more fine-grained analysis of the way news content changes over time. Finally, the vast majority of 
cross-national and single-country studies focus on Western democracies. Thus, our knowledge about recent changes in news content is limited to a small set of countries.

Overall, many studies provide evidence for constant changes of news content driven by social, political and economic developments. However, different media systems exhibit a sustained resilience towards transnational pressures reflected in a persistence of national differences in news content over time.

Keywords: News, Longitudinal analysis, International comparison, Convergence, Homogenization, Commercialization, News content, Media change, Journalism Studies

\section{Homogenization of News Content}

The 21 st century is marked by a fundamental transformation of journalism in many Western countries as a result of structural changes. The digitalization of news and the collapse of business models that formerly enabled commercial organizations to sell audiences to advertisers have changed news production profoundly (Bennett, 2012; Downie \& Schudson, 2009; Barnhurst, 2016). This recent development comes on top of structural changes that have been affecting the production of news for several decades, such as the increasing distance of the media to the political field and increasing commercialization. Scholars and professionals alike have feared that changes to global media markets, technological development, and the globalization of political communication led to decreased pluralism and a homogenization of news contents across countries (Bennett, 2004; Dworak, Lovett, \& Baumgartner, 2014; Humprecht \& Büchel, 2013; Powers \& Benson, 2014). As Hallin \& Mancini (2004, p. 26) said, "homogenization is to a significant degree a convergence of world media toward forms that first involved in the United States." This kind of 'Americanization' is understood as a linear diffusion process from the US to other countries, making it one important driver for a 
potential convergence of news content. As a result, news content might not meet democratic expectations of journalistic accountability anymore (Mazzoleni \& Schulz, 1999; Nielsen, 2013).

In addition to "Americanization" and "homogenization," the concept of "mediatization" (however broadly or narrowly defined) is frequently mentioned to explain current changes in news production (Hoskins \& O’Loughlin, 2015; Landerer, 2013; Strömbäck \& Esser, 2014; Strömbäck \& Esser, 2015). Although these concepts refer to transnational processes, there are still relatively few studies empirically examining the possible impact of political and media structures on news content in general and on the quality of news in a diachronic perspective in particular (Van Aelst et al., 2017). A minority of longitudinal studies combine a diachronic analysis with a cross-national comparison. Considering the scientific advantages of cross-national research, this avenue of research particularly helps researchers to understand whether current changes are likely to become long-term trends and, more importantly, which changes of structural conditions explain these trends. Against this background, we focus primarily on diachronic cross-national studies and secondarily single-country studies with a longer time span (around twenty years or more). The vast majority of studies falling into these categories deals with the US and Europe and therefore these countries guide the selection. However, we include studies dealing with a broader set of countries whenever available. In the following sections, we begin with an overview of cross-national studies, followed by single-country studies, before we turn to an overall assessment of the dominant themes and gaps in research on changes in news.

\section{Changes in News Content}

Research on long-term trends in news content is often built on the normative proposition that (political) news is an important resource for citizens, as well as for politicians and that democracy only functions if people have sufficient access to information relevant to 
society (Esser et al., 2012; Ferree, Gamson, Gerhards, \& Rucht, 2002; McQuail, 2013). Since the 1990s, an intensified debate about eroding trust in political institutions, news media, and political cynicism has triggered research on long-term changes in news content. Since then, a small, albeit growing number of comparative studies have been conducted, many of them enriching the field by putting national developments into context. This trend reflects a growing professionalization of the field. However, this does not mean that diachronic singlecountry studies are not any longer. These studies often still provide a detailed picture of current changes in news content and are especially beneficial when integrated into the comparative literature. Moreover, these studies frequently analyze different types of news outlets, from print to online to TV to radio, and thus provide missing evidence to comparative work.

In the following section, we will provide an overview of cross-national studies focusing on changes in news content caused by major global developments, such as commercialization, changes in the political environment and transnationalization. Subsequently, single-country studies will be discussed as we take a closer look at news production on a national level, focusing on prominently discussed phenomena such as the impact of commercialization and personalization and intimization of politics.

\section{Cross-national comparative studies}

As the parameters of news production have changed and economic pressures on news organizations have risen, the supply of political news has often been raised as a concern (Aalberg, van Aelst, \& Curran, 2010; McManus, 2009; Van Aelst et al., 2017). Moreover, some have argued that the increasing commercialization of media markets has led to the convergence of news content across countries. In Hallin and Mancini’s (Hallin \& Mancini, 2004) landmark study of Western media systems, the authors concluded that increasing commercialization diminishes national differences in news content. However, those authors 
argued that it remained an open question whether commercialization has increased or decreased the amount of political information, as the empirical evidence at the time was fragmentary and not entirely consistent (Hallin \& Mancini, 2004). To fill this gap, researchers started to investigate whether commercialization shapes news performance over time and whether this leads to a decrease of political, diverse, or objective news content.

\section{Commercialization}

To provide the missing empirical evidence, several studies analyzed differences in news content between various media systems. For example, Benson \& Hallin (2007) compared national newspapers for the U.S. and France from the 1960s to the 1990s. The two countries were chosen because of their contrasting structures: a highly commercialized press system in the US and higher degrees of political partisanship in France. The results showed that despite the globalization, differences in news content between the two countries had not diminished. The authors assumed that the proximity of the political and journalistic systems in France would lead to less critical coverage of politics and the government. However, the results showed higher levels of news stories with a critical or partisan tone and a prevalence of political scandals in French news content. Moreover, the French press offered a broader range of the viewpoints of civil society. In general, differences in writing style, level of criticism or viewpoints represented did not diminish over time - results contradicted the expectation of a homogenization driven by globalization.

To take a closer look at the differences between the U.S. and France, Benson (2010) examined how critical newspapers from these countries were in their news coverage in the 1990s and 2000s. More precisely, he measured whether critical statements targeted national players, such as those among the government, political parties, business or civil society, and what kind of focus these statements had (e.g., truth, ideology, policy, or strategy). His results widely confirmed those of Benson \& Hallin (2007) as he also found higher levels of critical 
statements in the French press. However, the gap narrowed between the 1990s and the 2000s due to a small drop in U.S. criticism and a much larger drop in French criticism. Benson (2010) concluded that this development was driven by increasing commercialization and secularization across Western countries.

Udris and Lucht (2014) compared the amount of political news, sensationalism and personalization in the printed press across Austria, France, Germany, Switzerland and the UK. Those authors only found a slight decrease of political content from 1960 until 2005 and constant, low levels of sensationalism. Personalization increased in the British mid-market sector, while in Austrian, German, and Swiss newspapers, constant levels of personalization were observed. Hence, the authors concluded that despite the transnational processes, such as globalization and commercialization, national differences in news content persisted.

In a similar attempt, Umbricht and Esser (2014) compared levels of opinionorientation, objectivity and negativity across different media system types. Those authors found partial evidence for a convergence trend. The degree of opinion-orientation converged in all Western media systems under study. While in the 1960s the polarized-pluralist systems of France and Italy had the highest shares of commentary and opinion and the liberal systems of UK and US had lowest, the levels narrowed over time. In the 2000s, the highest levels of opinion-oriented coverage were produced in the UK and Italy, followed by Switzerland and France. A different outcome occurred for the analysis of objectivity-related news practices. The authors found a constant increase of related practices, such as the inclusion of opposing viewpoints, the use of expert sources, direct quotations and indirect speech, as well as a hardfacts-first-structure in most countries under study. In the U.S., Germany and Switzerland, objectivity seemed to be an important norm in the 1960s, and news outlets from those countries continued to offer the highest levels of objectivity-related practices in the 2000s. Regarding negativity, the analysis produced mixed results. The authors assumed that 
commercialization and critical professionalism in the Anglo-Saxon countries lead to similar levels of negativity in polarized-pluralist countries that are characterized by polarization and inter-party contestation. As expected by the authors, elements of negativity, such as a negative story tenor, a conflict-oriented frame or an incompetence frame, were most frequently found in French and Italian newspapers in the 1960s. In contrast, in the consensus democracies of Switzerland and Germany, the lowest levels of negativity were found. Levels of negativity increased in the liberal countries - U.K. and U.S. - until the 2000s - a result contrary to the assumption that increased commercialization and critical professionalism caused homogenizing tendencies. Similar results were found in a follow up study, in which the authors looked at levels of sensationalization, scandalization, emotionalization, common people narratives, and privatization (Umbricht \& Esser, 2016). The results showed a general increase of the measured popularization techniques but no systematic evidence for a convergence of these reporting-styles in the press under study.

Other authors studied the effects of commercialization in the context of mediatization. Magin $(2015,2017)$ analyzed election campaign coverage from 1949 to 2006 in quality newspapers with a similar design, comparing Germany and Austria. She concluded that the components of a "media logic" (partisanship, personalization, and detachment from policy) have developed erratically over time in both countries, which "contests the idea of mediatization as an incessant, general process" (p. 415). In line with the basic assumptions of commercialization, Magin (2015) found an increase of personalization-although with large fluctuations between elections - and an increasing detachment from policy issues. Using the same data and focusing on the concept of "tabloidization," Magin (2017) observed only a very modest increase of tabloidization, an increase of emotionalization in newspaper headlines, as well as of visuals depicting candidates. 
The degree of commercialization of media systems is also related to the role of public media in a media system. Several studies have shown that the public service-dominated European media systems supply higher levels of political information in TV news than that in the more market-oriented news outlets in the U.S., which offer smaller amounts of hard news (Curran, Iyengar, Brink-Lund, \& Salovaara-Moring, 2009; Iyengar, Hahn, Bonfadelli, \& Marr, 2009). Aalberg et al. (2010) built on these results with their longitudinal study, comparing the United States to five European counties from 1987 to 2007. Those authors found that the most commercialized media system, the United States, offered the lowest levels of political affairs news content during prime time. Furthermore, the results showed that political news content in the prime-time programming of major TV channels did not converge, and that, in contrast, the five democratic corporatist media systems from Northern Europe demonstrated resistance to "subordinating the needs of democracy to profit making" (Aalberg et al., 2010, p. 14).

To replicate these results on a broader scale, Esser et al. (2012) analyzed political news content in thirteen European media systems over three decades. Those authors found that political TV news programming expanded since the 1970s in most countries partially because of the entrance of commercial TV stations into national media markets. Moreover, the authors found that public TV channels in the majority of countries provided higher levels of political information compared to their national private counterparts. However, private channels were found to adapt a similar mix of program genres over time as provided by public channels. Interestingly, Esser et al. (2012) identified different scheduling practices. In countries such as Belgium, Great Britain, Israel, the Netherlands, Norway and Sweden, the big TV channels offered their audiences multiple possibilities to get political news throughout the evening. Thus, viewers in these countries were more likely to encounter political and public affairs information than in more commercialized media systems, where political information was shifted to an early airtime in order to preserve the prime-time for 
entertainment. These practices aimed to maximize audiences at the expense of news media's information function.

In sum, cross-national research has established that large differences between media systems prevail despite global processes such as commercialization or mediatization. However, these studies focus on Western countries for the most part, and therefore the results discussed above can only speak for a small part of the world.

\section{Political environment}

Another strand of work in the field of news content addresses the impact of the political environment on news production. For instance, Manucci \& Weber analyzed the effects of successful populist parties on news content. In their study, they compared the levels of populist messages is newspaper articles from 1970 until 2010 in Switzerland, Germany, Austria, the Netherlands and the U.K. Although populist parties have gained power in those countries within the time span under study, newspaper coverage did not reflect this development. In contrast, levels of populist messages in the news were stable and did not reflect the increasing amount of populist messages found in party manifestos.

Scholars who stressed the importance of political structures frequently examined whether changes of institutional arrangements affect news content (e.g., the case of the European Union). Those studies have demonstrated the importance of the political environment. For example, Kriesi (2012) has analyzed media coverage on elections in a diachronic perspective. In his study on the personalization of politics from the 1970s to the 2000s in six Western European countries, he showed that there is no general trend of increasing personalization (when comparing individual politicians with organizations) or increasing focus on a limited set of political leaders. In his analysis, Kriesi (2012) argued that institutional arrangements of the respective political systems matter more than differences between media types (tabloid and quality papers). The overall degree of personalization and 
concentration of attention on the top candidates was highest in countries with (semi)

presidential systems and privileged positions of the executive, such as France or the U.K. and lowest in consensus democracies where power sharing had been traditionally widespread (e.g., Switzerland).

Along similar lines, Höglinger (2008) found evidence that news coverage still reflects the characteristics of different political systems. Examining news coverage on abortion in American, German and Swiss quality papers from 1971 to 1994 (to 2002 for the Swiss quality paper), differences between the three countries remain more important than the smaller changes within countries over time.

Political system characteristics have been found to play an important role when explaining differences in news content across countries. They shape the way politics is communicated by journalists in various countries. These patterns have been found to persist, even in times of political changes.

\section{Transnationalization}

Regarding the importance of transnationalization of political structures, a number of studies examined whether this development is also reflected in news content. Assuming that every political system is (and should be) inextricably linked to a public sphere and vice versa, the shift of political power to supra-national institutions is expected to be accompanied by a shift in news content as well. Several studies take the case of European integration as a prime example. Wessler et al. (2008), for instance, analyzed media coverage in routine periods in five European countries from 1982 to 2003 . They found only modest indications of a potential Europeanization, reflected in a slightly increasing focus on EU institutions and EU policies, as well as collective references to "Europeans". Two studies examining "crisis events" of post-War European history in different European countries from 1956 to the 2000s came to similar conclusions. Across the whole period, the conceptions of "Europe" and "values" 
discussed and conveyed in the media differed markedly across the countries under study (Krzyżanowski, M. Triandafyllidou \& Wodak, 2009; Krzyżanowski, 2009). National identity narratives prevailed even though references to Europe slightly increased and converged over time (Tréfás, 2012). In other words, those studies showed relatively little homogenization of news content across borders. Moreover, the European public sphere seemed to remain segmented along national public spheres. One reason for the remaining stratification is that quality papers tend to be more transnationalized in their reporting than tabloid papers (Wessler et al., 2008).

In sum, the cross-national research discussed above shows that media and political systems differences shape news content to a large degree. System differences have been found to outbalance global developments such as commercialization, changes in the political environment or transnationalization.

\section{Single-country studies}

While both diachronic and cross-national studies are still rare, there are more diachronic studies focusing on single countries. They are especially valuable if they are conducted with at least an 'implicit' comparison in mind. This means that the case selection must be clearly justified, and studies should aim to contextual and explain findings derived from comparative literature. In the following, we discuss studies that differ in their approaches, from quantitative to qualitative content analyses, from time spans covering "only" around twenty years to time spans covering hundred years, using different objects of analysis (e.g., elections or routine phases), as well as indicators. We cannot give an exhaustive overview of all possible diachronic studies, and we are aware that our selection is biased towards those studies published in languages with which we are more familiar. Moreover, we focus on two aspects which we consider the most predominant ones in the literature, namely, research on the outcomes of an overall commercial media logic (including 
several indicators at the same time) as well as research focusing on personalization and intimization of politics. Some of the studies discuss in the following point to stability over time, some provide ambivalent findings, and still others find distinct signs of change.

\section{Commercial Media Logic}

To begin with, some empirical studies that analyze the effects of a commercial media logic suggest no or only very modest changes in news content over time. One of Germany's leading quality papers, Frankfurter Allgemeine Zeitung, for instance, showed hardly any signs of “tabloidization” between 1982 and 2006 (Landmeier \& Daschmann, 2011). Marcinkowski et al. (2001, p. 106) looked at television news coverage during natural weeks and concluded that the coverage of politics in German TV stations showed an "astonishing degree of structural stability" from the 1970s to the 1990s. Bos \& Brants (2014) measured media attention to the populist style of political leaders in the Netherlands. Although the study identified patterns of market-oriented journalism, no increase of this type of journalism could be observed from 1994 to 2012 in broadsheets, tabloids or TV news.

Slightly more ambivalent findings were reported by McLachlan \& Golding (2000). In their content analysis of three British tabloids and two British quality papers from 1952 to 1997, they found an increase of human interest and entertainment reporting. At the same time, however, the number of political stories did not decrease. In another example, Winston (2002) showed that British TV programs offered notably less political reporting in their TV bulletins in 2001 than in 1975. However, he also showed that items were becoming longer, offering more opportunities to provide context. In the Netherlands, a study stretching from 1957 to 2006 showed that TV broadcasters aired more political information than before at the expense of entertainment and infotainment formats (van Santen \& Vliegenthart, 2013). At the same time, however, political information was broadcasted less often at prime time, especially on commercial channels. Similarly, Hubé (2014) studied news content of French newspapers 
between the 1970s and the 2000s and only found modest signs of tabloidization. The newspapers under study continued to provide high levels of political news stories with a strong focus on national politics. However, the results showed that the journalistic style changed over time to be more audience-oriented, and political processes were more often presented as a game.

In contrast to the studies indicating few or ambivalent findings mentioned above, the majority of the diachronic single-country studies showed substantial changes in news content over time, even in countries with different media systems. One often-quoted report by Patterson (2000) showed that from 1980 to 1998, American media (31 print outlets and two TV networks) devoted increasing attention to sensationalist and human-interest stories at the expense of hard news. In a study on election news on TV networks in the United States from 1988 to 2008, Farnsworth and Lichter (2011) analyzed phenomena such as horse race or problems of accuracy and fairness. In their normative assessment, they concluded that news coverage on network television has markedly changed and become worse in this period. Similarly, Imhof (2016) studied an extensive database of "communication events" in Swiss newspapers from 1910 to 2011 and found that the amount of scandal reports increased massively since the early 1990s. In addition, Kepplinger's (2000) study on three German quality newspapers from 1951 to 1995 also provided clear evidence for a growing negativity in political news reporting. In a more recent study on Germany, increasing shares of "commercial logic characteristics" were shown for one quality paper, one tabloid paper and one major TV newscast in a timespan from 1984 to 2014 (Karidi 2017).

Using a more qualitative approach, Meyen (2015) observed similar trends in Germany. He examined a broad range of events reported by three different newspapers from the 1950s to the 2010s, including party conventions, the general state budget debate in parliament, premieres of James Bond movies, the Eurovision Song Contest, storms, and more. The 
findings showed that newspapers in the 1950s used to devote more attention to political routine events, such as budget debates, compared to the 2010s. Moreover, they devoted less attention to emotions and "atmospheric" details (e.g., politicians sitting in Parliament using their iPads while another politician was giving a speech). Meyen (2015) concluded that newspapers increasingly select, interpret and portray events according to a commercial logic in order to trigger the attention of media consumers. Similarly, Brants \& van Praag (2006) analyzed Dutch media coverage during three election campaigns and found noticeably more elements of commercial media logic in the 2000s compared to the 1980s and 1950s, e.g., an increase in horse-race reporting at the expense of substantive reporting. A study on Belgian newspapers from 1981 to 2001 comparing different media types showed that only the tabloid paper and the mid-market paper showed signs of commercialization (Hauttekeete 2005). Notable changes in the news content of tabloids were also observed in Great Britain. Analyzing editions from 1968 to 1998 with a limited set of variables, Rooney (2000, pp. 101102) showed a declining share of public affairs content, which led him to conclude that "the Mirror and the Sun have abandoned the public sphere," In addition, regarding diversity of news coverage, Tan \& Weaver (2013) found a slight downward linear trend in the New York Time's agenda diversity, which was attributed to market pressures and media concentration.

\section{Personalization and Intimization}

Another strand of diachronic single-country studies focuses on one or a few indicators, often pointing at increasing personalization or intimization of political news coverage. As for personalization, in a broad theoretical perspective and through his extensive content analyses of US American newspapers since the late $19^{\text {th }}$ century, Barnhurst (2007) finds that, in the course of the $20^{\text {th }}$ century, individuals have lost much of their visibility in news at the benefit or social groups; especially ordinary, "average" persons speaking for themselves against the background of their lifeworld have become much less important than persons who speak for 
organized groups, particularly persons with authority and expert knowledge such as political leaders (cf. also Barnhurst, 2016). Examining election news coverage in Israel from 1949 to 2003, Rahat \& Sheafer (2007) showed increasing personalization, i.e., a growing focus on political leaders (instead of parties) and their political behavior. In the case of Switzerland, media attention to executive elections instead of parliamentary elections was much higher in the 2000s compared to the 1960s and 1970s, reflecting an increasing focus on prominent and powerful leaders (Udris, Lucht \& Schneider, 2015). The tabloid paper in particular focused much earlier and much more on this more 'dramatic' type of election compared to the examined mid-market paper or quality papers. Therefore, Udris, Lucht \& Schneider (2016) attributed this finding to an increasing importance of the media logic. In a study on Sweden from 1979 to 2010, Bjerling (2012) found increasing elements of 'intimate politics', although his findings were ambivalent. References to personal characteristics, inner traits, families and partners of Swedish politicians increased, but mainly in tabloids and not in the quality press. Moreover, he did not find increased coverage of appearances of politicians, such as clothes, hairstyle, etc. Similarly, Sörensen (2016) found in her analysis of one important German news magazine from 1949 to 2012 that the German president (holding a mainly representative office) has become much more visible. However, the author found no clear trend towards an “intimization" of politics.

In sum, we found two major strands of work studying long-term trends in news. International comparisons aim to answer the question whether news content converges over time and, if so, whether this is driven by societal, political, and economic processes, such as commercialization, digitalization, or political polarization. In contrast, single-country studies examine the impact of these processes in national contexts aiming for identifying changes in news content. Many studies are concerned with the implications that changes in news content have for democracy. This is why many studies focus on aspects of news performance or news quality, such as tabloidization, scandalization or personalization. Although the majority of 
single-countries studies find an increase of these aspects in national news coverage, international comparisons show that there are only little signs of convergence. Thus, while we can observe similar trends in many countries that move in similar directions (e.g. tabloidization), these trends do not occur to the same degree. Moreover, national characteristics of media and political systems still seem to shape news production even in times of globalization and digitalization.

\section{Dominant Themes and Gaps in Research}

In international comparative research on long-term trends in news content, two opposing perspectives were found to be prevalent. The first assumes that (political) journalism in Western countries has undergone a steady homogenization since the 1960s, driven by the diffusion of Anglo-American standards and by a potential imitation of successful news outlets such as the News York Times, the Washington Post, and others. Representatives of this perspective fear that a potential convergence might lead to decreased pluralism and a synchronization of news at the expense of national and local media companies, and public broadcasting in particular (McManus, 2009). One could also argue that this perspective is also dominant in many single-country studies.

The second perspective highlights differences in national media systems and news cultures that seem to resist globalization. Hallin and Mancini $(2004,2012)$ have argued that certain characteristics of national media systems, such as journalistic professionalism or the degree of political parallelism, shape the production and thus the content of news. Moreover, cross-national differences in news content have been explained by historical processes and the formation of news media as social institutions (Vartanova, 2012; Voltmer, 2012; Zhao, 2012). From an institutionalist perspective, news outlets are entities sharing similar sets of norms and practices (Shoemaker \& Reese, 2013). However, when the environments in which news 
outlets operate change, many scholars argue it is likely to be reflected in the content produced.

In research on long-term trend in news content, we found evidence for both perspectives. In short, single-country studies tend to support the first perspective (homogenization) and international comparative studies tend to support the second perspective (remaining differences). This might be related with the respective approach since single-country studies focus on change and cross-national studies focus on differences across countries. However, some cross-national comparative studies also find tendencies of convergence, for instance in terms of the adaption of certain formats and styles (Hubé, 2014). Most studies, nevertheless, suggest that cross-national differences persist in times of globalization and commercialization (Esser, 2008; Esser \& Umbricht, 2013). Therefore, some authors argue that the idea of convergence is largely exaggerated (Aalberg \& Curran, 2012). One reason is that until recently, journalistic professionalism maintained a 'firewall' between journalism and the management, hence advertisers had limited direct control over news production (Cushion, 2012; Downie \& Schudson, 2009). However, the existential crisis of many media organizations caused by a drift of advertisers and audiences to the Internet stoked fears of a declining supply of information and quality of news (Carson, 2014; Nel, Levy, \& Nielsen, 2012; Picard, 2010). The empirical evidence, nevertheless, is less worrisome. Recent studies have shown that a large part of established media organizations retain their professional standards also in the online age (Carpenter, 2010; Curran et al., 2013; Humprecht, 2016; Humprecht \& Esser, 2016).

Reviewing the literature on long-term trends in news content, notable gaps can be observed. One gap concerns the periods that scholars examine. There is a clear dominance of studies focusing on routine periods and on elections, neglecting other periods and phases in the political process. Studies on routine periods usually rely on samples which consist of 
constructed weeks or randomly sampled days. These studies fulfill an important function, as they are considered representative for news in general at a certain point in time. Studies on elections also have several advantages. First, they are representative as elections usually take place regularly. Second, they include an important period, as elections are especially important from a normative perspective and from a practical perspective when both journalists and politicians increase their activities to address citizens (Van Aelst \& De Swert, 2009). Third, they are closely tied to institutional arrangements, which makes cross-country comparisons easier as political system or political culture variables can be used as explanatory factors.

These examples illustrate that diachronic studies tend to focus on those periods and events that can be more easily "controlled" in a research design. Against this background, it is surprising that there are hardly any longitudinal studies on how the media covers and constructs political protests, upheavals and crises. Regarding activities of protest movements, several studies work with databases such the Prodat database in Germany (Rucht, 2003) or a database on political conflicts in Europe (Koopmans, Statham, Giugni, \& Passy, 2005; Kriesi et al., 2008). However, those studies see media mainly as a mirror for social processes. Thus, news coverage is mainly used as an indicator for the 'real' amount of protest, the action repertoires of political activists and the activities of other political actors against protest actors. However, research focusing on the role of the media itself, such as studies on the “protest paradigm” (Weaver \& Scacco, 2013), rarely employ longitudinal designs and only focus on "institutionalized" forms of political protests such as demonstrations (McCarthy, McPhail, \& Smith, 1996).

Similarly, disruptive or "critical events" play hardly any role in diachronic studies. Events such as referenda with far-reaching impact (e.g., the referenda in Great Britain on Europe in 1975 and 2016), wars, catastrophes (e.g., nuclear disasters), "moral panics" such as 
health epidemics or the fear of "mugging" in the 1970s (Hall, Critcher, Jefferson, Clarke, \& Roberts, 1978), political scandals (e.g., revelation of corruption) or even important takeovers in the media sector are hardly studied. They might seem to be too idiosyncratic for a meaningful comparison over time and across countries. At the same time, not including "critical events" also means to neglect exactly those events that are especially important for the media and society as a whole.

Another gap in the English-speaking literature is the lack of studies analyzing news content from countries other than the United States and Europe. Only few studies covering countries such as Israel, Chile, or China exist and provide valuable insights in news practices beyond the Western world (Dong, Chang, \& Chen, 2008; Mellado \& Humanes, 2015; Tenenboim \& Cohen, 2015). However, longitudinal studies on news content in comparative perspective are still extremely rare. This means that our knowledge of how news coverage has changed in recent decades is built on evidence from a very limited set of countries. To better understand whether global developments lead to similar outcomes around the globe, more “non-Western" studies are needed.

\section{Discussion}

Research on long-term trends in news content has repeatedly shown the resilience of national media systems toward transnational pressures. It can be concluded that although news content changes over time, cross-national differences persist - even in times of transnational developments, such as globalization, digitalization, and commercialization. Those findings show the importance of journalistic norms and practices in shaping news content. As cross-national studies show, journalistic professionalism in many Western democracies seems to be relatively robust even if the political environment changes.

However, despite the obvious merit of cross-country comparative studies, research on long-term trends also has some major weaknesses. One of them is the reluctance to explicitly 
address normative issues. Many studies implicitly work with normative models of democracy, but they do not discuss their underlying assumptions. This is also reflected in the scope of social theory underlying most diachronic studies on news content. In general, the literature on "mediatization," which is a major concept used in studies dealing with the commercialization or homogenization of news content, tends to focus on the functional dimension of social differentiation. Typically, debates on the potential mediatization of politics and commercialization of news media are linked to the functional dimension of social differentiation, as postulated by theories of media systems and (new) institutionalism. This means that questions of the relationship between the media, political and economic systems are often in the foreground. This also means that research tends to neglect the other two forms of social differentiation. First, it neglects the segmentary dimension of social differentiation and rarely examines issues of transnationalization on the level of news content. Second, it neglects the stratificatory dimension and therefore only rarely touches upon questions of power and social (in)equality (Imhof, 2011). In this line of reasoning, Curran (2011) criticizes Hallin and Mancini's (2004) “catch-all category” of the 'Liberal Model' because it does not take social inequality into account.

It could be assumed that current debates over political polarization, fragmentation and ongoing media concentration have made scholarship more aware of questions concerning growing inequality (stratification) and segmentation. However, more attention should be paid to new allocations of power in this context. This includes an increasing division between "upmarket" and "down-market" news outlets, as well as opportunity structures for new powerful and/or populist actors to set the media agenda and influence news coverage. On the segmentary dimension, scholars should examine more closely the relationship between various layers of local, national, transnational and international reporting and how these are affected by commercialization. Thus, scholars need to deal more systematically with a potentially increasing disentanglement between the political and media domains, for instance 
when regional and supra-national levels lack a corresponding public sphere. Moreover, there is a need for research dealing systematically with the question how different segments of society are covered in the media over time (e.g., minorities). Ideally, different dimensions of social differentiation are combined. One of the few examples is the study by Wessler et al. (2008). Those authors analyzed the importance of foreign news coverage and European news coverage over time, systematically examining chances of attention for non-established actors. Furthermore, the study looked at different types of media linked to different strata of society (stratificatory) and shaped by market pressures and commercialization (functional). Finally, although research might not be able to examine all different dimensions at the same time, scholars should be more explicit about their normative appraisals (Althaus, 2012).

This also brings us to the point of scholarly engagement in public debates. Many studies on long-term trends in news content highlight the fact that media has taken a central place in modern societies and that media in a free public sphere is inextricably linked to a democratic model of society. Therefore, there is a call for scholars to discuss their findings on long-term trends in news content with media practitioners, political actors and the general public (Nielsen, 2017). Only few on-going projects in this field exist that have actively engaged in public discourse. While the pioneering "Project for Excellence in Journalism" in the United States has provided ample material on news content, it has moved its focus away from content analyses and shifted towards surveys of news consumption. In Switzerland, scholars every year publish a "Yearbook Quality of the Media" on news content from different types of media which addresses the general public (fög - Forschungsinstitut Öffentlichkeit und Gesellschaft, 2018). In Chile, scholars have developed a measurement of news quality and applied it to news coverage in Spain and Latin American countries since the 1990s (Pellegrini, Puente, Porath, Mujica, \& Grassau, 2011). More efforts should be taken to implement this kind of research across countries and especially over time. 
Finally, another shortcoming of current research on long-term trends in news content is the lack of studies analyzing digital media. Even in recent years, the vast majority of diachronic studies in the field have focused on traditional news media, such as quality newspapers and major TV stations. However, traditional news media is facing increasing competition for attention by new players, among them hyperpartisan news outlets, such as Breitbart in the United States. Against the background that a significant share of citizens in most Western countries consume news via social media, those players gain more and more importance. In the social media environment where users predominantly look for entertainment and relaxation, sensational, emotional and partisan news content is likely to diffuse more rapidly than hard news content (Shin \& Thorson, 2017; Valenzuela, Piña, \& Ramírez, 2017). The massive diffusion of disinformation on social media during the 2016 U.S. presidential campaign and the "Brexit" campaign in the U.K. show the worrisome potential of these new logics of the sharing and liking economy. Against the background of an ever-changing online environment, longitudinal studies are needed to identify current trends in news reporting. Furthermore, in light of multiplatform news production and news consumption, we also need to understand what kind of news is offered to people consuming news on different platforms, for instance looking at social media compared to news websites. Therefore, future research should widen its scope and examine news content on different platforms over time, such as on social media, professional, partisan, or alternative news websites, and across platforms. A comparison of a news website before the advent of social media with news published on the outlet's social media accounts could be one way to complete this analysis. Moreover, there is a need for identifying cross-national differences in order to understand whether these developments are universal, how they shape journalistic news production and what kind of news is offered to citizens around the globe. 


\section{Further Readings}

Benson, R. (2013). Shaping Immigration News. Shaping Immigration News: A FrenchAmerican Comparison. Cambridge, Massachusetts: Cambridge University Press.

de Vreese, C. H., Esser, F., \& Hopmann, D. N. (2016). Comparing Political Journalism. London and New York: Routledge.

Couldry, N. (2008). Mediatization or mediation? Alternative understandings of the emergent space of digital storytelling. New Media \& Society, 10(3), 373-391. https://doi.org/10.1177/1461444808089414

Hallin, D. C., \& Mancini, P. (2012). Comparing media systems beyond the Western world. Cambridge University Press.

Hallin, D. C., \& Mancini, P. (2004). Comparing Media Systems. Three Models of Media and Politics. Cambridge: Cambrige University Press.

Kuhn, R., \& Nielsen, R. K. (2013). Political Journalism in Transition: Western Europe in a Comparative Perspective. London: IB Tauris.

Strömbäck, J., \& Esser, F. (2015). Making Sense of Mediatized Politics. Theoretical and Empirical Perspectives. London: Routledge.

\section{References}

Aalberg, T., \& Curran, J. (2012). How Media Inform Democracy. A Comparatice Approach. London and New York: Routledge.

Aalberg, T., van Aelst, P., \& Curran, J. (2010). Media Systems and the Political Information Environment: A Cross-National Comparison. The International Journal of 
Press/Politics, 15(3), 255-271. https://doi.org/10.1177/1940161210367422

Althaus, S. L. (2012). What's Good and Bad in Political Communication Research?

Normative Standards for Evaluating Media and Citizen Performance. In H. A. Semetko \& M. Scammell (Eds.), The SAGE Handbook of Political Communication (pp. 97-112). London: SAGE Publications Ltd.

Barnhurst, K. G. (2016). Mister Pulitzer and the Spider: Modern News from Realism to the Digital. Champaign, Illinois: University of Illinois Press.

Barnhurst, K. G. (2007). Ideology and the Changing Representations of Persons in U.S. Journalism. In M. Broersma (Ed.), Form and Style in Journalism. European Newspapers and the Representation o News, 1880-2005 (pp. 219-234). Leuven, Paris, Dudley (MA): Peeters.

Bennett, L. W. (2004). Gatekeeking and Press-Gouvernment Relations: A Multigated Model of News Construction. In L. L. Kaid (Ed.), Handbook of Political Communication Research. Mahwah, New Jersey: Lawrence Erlbaum Associates, Publishers.

Bennett, L. W. (2012). News. The Politics of Illusion. Chicago: The University of Chicago Press.

Benson, R. (2010). What Makes for a Critical Press? A Case Study of French and U.S. Immigration News Coverage. The International Journal of Press/Politics, 15(1), 3-24. https://doi.org/10.1177/1940161209349346

Benson, R., \& Hallin, D. C. (2007). How States, Markets and Globalization Shape the News: The French and US National Press, 1965-97. European Journal of Communication, 22(1), 27-48. https://doi.org/10.1177/0267323107073746

Bjerling, J. (2012). The Personalisation of Swedish Politics. Party Leaders in the Election Coverage 1979-2010. Gothenburg, Swenden: University of Gothenburg. 
Bos, L., \& Brants, K. (2014). Populist rhetoric in politics and media: A longitudinal study of the Netherlands. European Journal of Communication, 29(6), 703-719.

Brants, K., \& van Praag, P. (2006). Signs of media logic. Half a century of political communication in the Netherlands. Javnost - the Public, 13(1), 25-40.

Carpenter, S. (2010). A study of content diversity in online citizen journalism and online newspaper articles. New Media \& Society, 12(7), 1064-1084. https://doi.org/10.1177/1461444809348772

Carson, A. (2014). The political economy of the print media and the decline of corporate investigative journalism in Australia. Australian Journal of Political Science, 49(4), 726-742. https://doi.org/10.1080/10361146.2014.963025

Curran, J. (2011). Media and Democracy. New York: Routledge.

Curran, J., Coen, S., Aalberg, T., Hayashi, K., Jones, P. K., Splendore, S., ... Tiffen, R. (2013). Internet revolution revisited: a comparative study of online news. Media, Culture \& Society, 35(7), 880-897. https://doi.org/10.1177/0163443713499393

Curran, J., Iyengar, S., Brink-Lund, A., \& Salovaara-Moring, I. (2009). Media System, Public Knowledge and Democracy: A Comparative Study. European Journal of Communication, 24(1), 5-26. https://doi.org/10.1177/0267323108098943

Cushion, S. (2012). The Democratic Value of News. Basingstoke: Palgrave Macmillan.

Dong, D., Chang, T. K., \& Chen, D. (2008). Reporting AIDS and the invisible victims in China: Official knowledge as news in the People's Daily, 1986-2002. Journal of Health Communication, 13(4), 357-374. https://doi.org/10.1080/10810730802063793

Downie, L., \& Schudson, M. (2009). The Reconstruction of American Journalism. New York. Dworak, B., Lovett, J., \& Baumgartner, F. R. (2014). The Diversity of Internet Media: Utopia 
or Dystopia? In Midwest Political Science Association (p. April 3-6). Chicago.

Esser, F. (2008). Dimensions of Political News Cultures: Sound Bite and Image Bite News in France, Germany, Great Britain, and the United States. The International Journal of Press/Politics, 13(4), 401-428. https://doi.org/10.1177/1940161208323691

Esser, F., de Vreese, C. H., Strömbäck, J., van Aelst, P., Aalberg, T., Stanyer, J., Reinemann, C. (2012). Political Information Opportunities in Europe. The International Journal of Press/Politics, 17(3), 247-274. https://doi.org/10.1177/1940161212442956

Esser, F., \& Umbricht, A. (2013). Competing models of journalism? Political affairs coverage in US, British, German, Swiss, French and Italian newspapers. Journalism, 14(8), 9891007. https://doi.org/10.1177/1464884913482551

Farnsworth, S. J., \& Lichter, S. R. (2011). The nightly news nightmare. Media coverage of U.S. presidential elections, 1988-2008. Lanham: Rowman \& Littlefield.

Ferree, M., Gamson, W. A., Gerhards, J., \& Rucht, D. (2002). Shaping Aborting Discourse. Democracy and the Public Sphere in Germany and the United States. Cambridge: Cambridge University Press.

fög - Forschungsinstitut Öffentlichkeit und Gesellschaft (2018). Jahrbuch Qualität der Medien. Basel: Schwabe.

Hall, S., Critcher, C., Jefferson, T., Clarke, J., \& Roberts, B. (1978). Policing the Crisis: Mugging, the State, and Law and Order. London: Palgrave Macmillan.

Hallin, D. C., \& Mancini, P. (2004). Comparing Media Systems. Three Models of Media and Politics. Cambridge: Cambrige University Press.

Hauttekeete, L. (2005). De tabloidisering van kranten: mythe of feit? De ontwikkeling van een meetinstrument en een onderzoek naar de tabloidisering van Vlaamse kranten. Gent: 
Universiteit Gent.

Höglinger, D. (2008). Verschafft die direkte Demokratie den Benachteiligten mehr Gehör? Der Einfluss institutioneller Rahmenbedingungen auf die mediale Präsenz politischer Akteure. Swiss Political Science Review, 14(2), 207-243.

Hoskins, A., \& O'Loughlin, B. (2015). Arrested war: the third phase of mediatization. Information Communication and Society, 18(11), 1320-1338. https://doi.org/10.1080/1369118X.2015.1068350

Hubé, N. (2014). Design is Content" On Tabloizidation of the French Quality Newspaper Journalism. In M. Broersma \& C. Peters (Eds.), Retelling Journalism. Conveying Stories in a Digital Age (pp. 107-128). Leuven, Belgium: Peeters.

Humprecht, E. (2016). Shaping Online News Perfomance. Basingstoke: Palgrave Macmillan.

Humprecht, E., \& Büchel, F. (2013). More of the Same or Marketplace of Opinions? A CrossNational Comparison of Diversity in Online News Reporting. The International Journal of Press/Politics, 18(4), 436-461. https://doi.org/10.1177/1940161213497595

Humprecht, E., \& Esser, F. (2016). Mapping digital journalism: Comparing 48 news websites from six countries. Journalism, 146488491666787. https://doi.org/10.1177/1464884916667872

Imhof, K. (2016). (2016): Political, Social, and Economic Crises in Public Communication. In A. Schwarz, M. W. Auer, \& C. Seeger (Eds.), The Handbook of International Crisis Communication Research (pp. 175-187). Hoboken, NJ: John Wiley \& Sons.

Iyengar, S., Hahn, K. S., Bonfadelli, H., \& Marr, M. (2009). "Dark Areas of Ignorance” Revisited: Comparing International Affairs Knowledge in Switzerland and the United States. Communication Research, 36(3), 341-358.

https://doi.org/10.1177/0093650209a333024 
Kepplinger, H. M. (2000). The Declining Image of the German Political Elite. The Harvard International Journal of Press/Politics, 5(4), 71-80.

Koopmans, R., Statham, P., Giugni, M., \& Passy, F. (2005). Contested Citizenship: Immigration and Ethnic Relations Politics in Europe. Minneapolis \& London: Minnesota University Press.

Kriesi, H. (2012). Personalization of national election campaigns. Party Politics, 18(6), 825844. https://doi.org/10.1177/1354068810389643

Kriesi, H., Grande, E., Lachat, R., Dolezal, M., Bornschier, S., \& Frey, T. (2008). West European politics in the age of globalization. Cambridge: Cambridge University Press.

Krzyżanowski, M. Triandafyllidou, A., \& Wodak, R. (2009). Conclusions: Europe, Media, Crisis and the European Public Sphere. In A. Triandafyllidou, R. Wodak, \& M. Krzyżanowski (Eds.), The European public sphere and the media. Europe in crisis (pp. 261-268). Basingstoke, New York: Palgrave Macmillan.

Krzyżanowski, M. (2009). Europe in crisis?: Discourses on crisis events in the european press 1956-2006. Journalism Studies, 10(1), 18-35. https://doi.org/10.1080/14616700802560468

Landerer, N. (2013). Rethinking the Logics: A Conceptual Framework for the Mediatization of Politics. Communication Theory, 23(3), 239-258. https://doi.org/10.1111/comt.12013

Landmeier, C., \& Daschmann, G. (2011). Im Seichten kann man nicht ertrinken? Boulevardisierung in der überregionalen deutschen Qualitätspresse. In R. Blum, H. Bonfadelli, K. Imhof, \& O. Jarren (Eds.), Krise der Leuchttürme öffentlicher Kommunikation - Vergangenheit und Zukunft der Qualitätsmedien (pp. 177-191). Wiesbaden: VS Verlag für Sozialwissenschaften.

Magin, M. (2015). Shades of Mediatization: Components of Media Logic in German and 
Austrian Elite Newspapers (1949-2009). International Journal of Press/Politics, 20(4), 415-437. https://doi.org/10.1177/1940161215595944

Magin, M. (2017). Attention, please! Structural influences on tabloidization of campaign coverage in German and Austrian elite newspapers (1949-2009). Journalism, 146488491770784. https://doi.org/10.1177/1464884917707843

Marcinkowski, F., Greger, V., \& Hünning, W. (2001). Stabilität und Wandel der Semantik des Politischen: Theoretische Zugänge und empirische Befunde. In F. Marcinkowski (Ed.), Die Politik der Massenmedien. Heribert Schatz zum 65. Geburtstag. (pp. 12-114). Köln: Herbert von Halem.

Mazzoleni, G., \& Schulz, W. (1999). "Mediatization” of Politics: A Challenge for Democracy? Political Communication, 16(3), 247-261. https://doi.org/10.1080/105846099198613

McCarthy, J. D., McPhail, C., \& Smith, J. (1996). Images of protest: Dimensions of selection bias in media coverage of Washington demonstrations, 1982 and 1991. American Sociological Review, 478-499.

McLachlan, S., \& Golding, P. (2000). Tabloidization and the British Press. A Quantitative Investigation into Changes in British Newspapers, 1952-1997. In C. Sparks \& J. Tulloch (Eds.), Tabloid Tales. Global Debates over Media Standards (pp. 75-90). Oxford: Rowman \& Littlefield.

McManus, J. H. (2009). The Commercialization of News. In K. Wahl-Jorgensen \& T. Hanitzsch (Eds.), The Handbook of Journalism Studies (pp. 218-233). New York and London: Routledge.

McQuail, D. (2013). Journalism and society. London: SAGE Publications, Inc.

Mellado, C., \& Humanes, M. L. (2015). The Use of Objective and Analytical Reporting as a 
Method of Professional Work: A Cross-Longitudinal Study of Chilean Political

Coverage. International Journal of Press/Politics, 20(1), 67-84.

https://doi.org/10.1177/1940161214558125

Meyen, M. (2015). Aufmerksamkeit, Aufmerksamkeit, Aufmerksamkeit. Publizistik, 60(1), 21-39. https://doi.org/10.1007/s11616-014-0219-z

Nel, F., Levy, D., \& Nielsen, R. K. (2012). The Changing Business of Journalism and Its Implications for Democracy. Journalism Studies, 13(3). Retrieved from http://www.tandfonline.com/doi/full/10.1080/1461670X.2012.662412

Nielsen, R. K. (2013). The absence of structural Americanization: media system developments in six affluent democracies, 2000-2009. The International Journal of Press/Politics, 18(4), 392-412.

Nielsen, R. K. (2017). No One Cares What We Know: Three Responsesto the Irrelevance of Political Communication Research. Political Communication, 00(00), 1-5. https://doi.org/10.1080/10584609.2017.1406591

Patterson, T. E. (2000). The United States: News in a Free-Market Society. In R. Gunther \& A. Mughan (Eds.), Democracy and the Media (pp. 241-265). Cambridge, Massachusetts: Cambridge University Press.

Pellegrini, S., Puente, S., Porath, W., Mujica, C., \& Grassau, D. (2011). Valor Agregado Periodístico: la apuesta por la calidad de las noticias. Santiago, Chile: Ediciones UC.

Picard, R. G. (2010). A Business Perspective on Challenges Facing Journalism. The Changing Business of Journalism and Its Implications for Democracy, (1), 17-24.

Powers, M., \& Benson, R. (2014). Is the Internet Homogenizing or Diversifying the News? External Pluralism in the U.S., Danish, and French Press. The International Journal of Press/Politics. https://doi.org/10.1177/1940161213519680 
Rahat, G., \& Sheafer, T. (2007). The Personalization(s) of Politics: Israel, 1949-2003. Political Communication, 24(1), 65-80. https://doi.org/10.1080/10584600601128739

Rooney, D. (2000). Thirty Years of Competition in the British Tabloid Press: The Mirror and the Sun 1968-1988. In C. Sparks \& J. Tulloch (Eds.), Tabloid Tales. Global Debates over Media Standards (pp. 91-109). Oxford, UK: Rowman \& Littlefield.

Rucht, D. (2003). The changing role of political protest movements. West European Politics, 26(4), 153-176.

Shin, J., \& Thorson, K. (2017). Partisan Selective Sharing: The Biased Diffusion of FactChecking Messages on Social Media. Journal of Communication, 67(2), 233-255. https://doi.org/10.1111/jcom.12284

Shoemaker, P. J., \& Reese, S. D. (2013). Mediating the Message in the 21 st Century A Media Sociology Perspective. New York and London: Routledge.

Sörensen, J. (2016). The German federal president in the press: Public officeholder or private citizen? European Journal of Communication, 31(3), 243-259. https://doi.org/10.1177/0267323116629878

Strömbäck, J., \& Esser, F. (2014). Making sense of the mediatization of politics. Journalism Studies, 15(3), 37-41. https://doi.org/10.1080/ 1461670X.2014.897412

Strömbäck, J., \& Esser, F. (2015). Making Sense of Mediatized Politics. Theoretical and Empirical Perspectives. London: Routledge.

Tan, Y., \& Weaver, D. H. (2013). Agenda Diversity and Agenda Setting From 1956 to 2004. Journalism Studies, 14(6), 773-789. https://doi.org/10.1080/1461670X.2012.748516

Tenenboim, O., \& Cohen, A. A. (2015). What prompts users to click and comment: A longitudinal study of online news. Journalism, 16(2). 
https://doi.org/10.1177/1464884913513996

Tréfás, D. (2012). The Europeanization of National Identities. Results of a Content Analysis in six European Countries from 1956 to 2003. In D. Tréfás \& J. Lucht (Eds.), Europe on Trial: Shortcomings of the EU with Regard to Democracy, Public Sphere, and Identity (pp. 106-124). Innsbruck: Studienverlag.

Udris, L., \& Lucht, J. (2014). Mediatization at the System Level: Independence from Politics, Dependence on the Market. In F. Esser \& J. Strömbäck (Eds.), Mediatization of Politics: Understanding the Transformation of Western Democracies (pp. 114-136). Basingstoke: Palgrave Macmillan.

Udris, L., Lucht, J., \& Schneider, J. (2015). Contested federal elections in increasingly commercialized media. A diachronic analysis of elections news coverage in Switzerland. Swiss Political Science Review, 21(4), 578-595. https://doi.org/10.1111/spsr.12171

Umbricht, A., \& Esser, F. (2014). Changing Political news? Long-Term Trends in American, British, French, Italian, German, and Swiss Print Media Reporting. In R. Kuhn \& R. K. Nielsen (Eds.), Political Journalism in Transition (pp. 195-218). London: I.B. Tauris.

Umbricht, A., \& Esser, F. (2016). The Push to Popularize Politics. Journalism Studies, 17(1), 100-121. https://doi.org/10.1080/1461670X.2014.963369

Valenzuela, S., Piña, M., \& Ramírez, J. (2017). Behavioral Effects of Framing on Social Media Users: How Conflict, Economic, Human Interest, and Morality Frames Drive News Sharing. Journal of Communication, 67(5), 803-826. https://doi.org/10.1111/jcom.12325

Van Aelst, P., \& De Swert, K. (2009). Politics in the news: Do campaigns matter? A comparison of political news during election periods and routine periods in Flanders (Belgium). Communications, 34(2), 149-168. https://doi.org/10.1515/COMM.2009.011 
Van Aelst, P., Strömbäck, J., Aalberg, T., Esser, F., de Vreese, C. H., Matthes, J., ... Stanyer, J. (2017). Political communication in a high-choice media environment: a challenge for democracy? Annals of the International Communication Association, 41(1), 3-27. https://doi.org/10.1080/23808985.2017.1288551

Van Santen, R., \& Vliegenthart, R. (2013). TV programming in times of changing political communication: A longitudinal analysis of the political information environment. European Journal of Communication, 28(4), 397-419. https://doi.org/10.1177/0267323113486417

Vartanova, E. (2012). The Russian Media Model in the Context of Post-Soviet Dynamics. In D. C. Hallin \& P. Mancini (Eds.), Comparing Media Systems Beyond the Western World (pp. 119-142). Cambridge, Massachusetts: Cambridge University Press.

Voltmer, K. (2012). How far can media systems travel. In D. C. Hallin \& P. Mancini (Eds.), Comparing media systems beyond the Western world (pp. 224-245). Cambridge, UK: Cambridge University Press.

Weaver, D. A., \& Scacco, J. M. (2013). Revisiting the protest paradigm: The Tea Party as filtered through prime-time cable news. The International Journal of Press/Politics, $18(1), 61-84$.

Wessler, H., Skorek, M., Kleinen-von Konigslow, K., Held, M., Dobreva, M., \& Adolphsen, M. (2008). Comparing Media System and Media Content: Online Newspapers in Ten Eastern and Western European Countries. Journal of Global Mass Communication, 1(3/4), 165-189.

Winston, B. (2002). Towards tabloidization? Glasgow revisited, 1975-2001. Journalism Studies, 3(1), 5-20.

Zhao, Y. (2012). Understanding China's media system in a world historical context. In D. C. 
Hallin \& P. Mancini (Eds.), Comparing media systems beyond the Western world (pp. 143-176). Cambridge, UK: Cambridge University Press. 